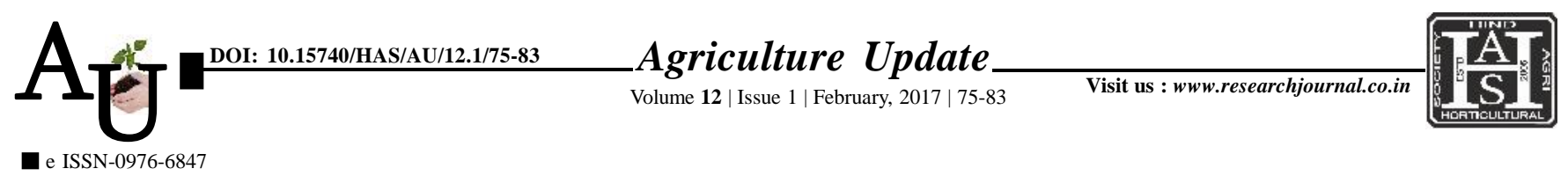

\title{
Research Article: Extent of adoption of potato production technology by the potato growers in Sabarkantha district of Gujarat
}

\author{
MANOJ R. MANE, NILESH P. TAYADE AND MAHESH M. KADAM
}

Article Chronicle: Received : 06.12.2016;

Revised :

23.12.2016;

Accepted :

01.01 .2017

KeY Words:

Adoption, Production technology, Potato growers

Author for correspondence :

\section{NILESH P. TAYADE}

Shramshakti College of Agriculture (M.P.K.V.), Maldad, SANGMANER

\section{(M.S.) INDIA}

Email:nilesh5novembetr @ gmail.com; mahesh.20181@1pu.co. in

See end of the article for authors' affiliations
SUMMARY : Horticulture sector covering only 8.00 per cent of total cropped area in the country and it contributes 24.50 per cent to G.D.P. and 54.55 per cent to export earning in agriculture sector. Potato is an important vegetable crop of the Sabarkantha district of the Gujarat state occupying about 18.46 per cent of total potato cropped area of the state. It ranks second in area and production of potato after Banaskantha district. While it ranks fourth with average productivity $31.04 \mathrm{MT} / \mathrm{ha}$ after Gandhinagar (33.75 MT/ha), Anand (32.00 MT/ha) and Banaskantha (31.05 MT/ha). The specific objectives studied were, to study the personal, socio-economic, situational and psychological characteristics of the potato growers, to find out knowledge level of the potato growers about potato production technology, to find out the extent of adoption of potato production technology by the potato growers. The results revealed that majority ( $56.67 \%$ ) of the potato growers were found in the middle age group and majority $(35.83 \%)$ of the potato growers were educated upto high secondary level. Nearly half $(54.17 \%)$ of the respondents belonged to medium size of family, majority (60.83\%) of the potato growers had membership in one organization, more than two-fifths $(42.50 \%)$ of the potato growers were semi-medium farmers having 2.01 to 4.0 ha of land, majority $(67.50 \%)$ of the potato growers were found with medium annual income and majority (71.67\%) of the potato growers fell in medium category of the extension participation. Three-fifths (61.67\%) of the potato growers had adopted drip as a method of irrigation and majority $(63.33 \%)$ of the farmers had adopted groundnut-potato-fodder sorghum potato based cropping pattern, more than three-fourths $(75.83 \%)$ of the potato growers had medium innovative proneness and nearly three- fifths $(60.00 \%)$ of the potato growers had medium risk orientation. A great majority $(61.67 \%)$ of the potato growers had medium level of knowledge regarding recommended practices of potato. The findings regards to the practice-wise knowledge of the respondents about recommended potato production technology are presented. It reveals that 'sowing time and method' and 'irrigation management' were the most important practices of potato cultivation and found having maximum mean knowledge score ( 93.33 mean score each). Majority $(70.83 \%$ ) of the respondents had medium extent of adoption of recommended production technology of potato. The practice-wise adoptions of recommended production technology of potato concluded that among the different recommended potato production technologies, $(86.57$ mean score) of the respondents had adopted irrigation management technology.

How to cite this article : Mane, Manoj R., Tayade, Nilesh P. and Kadam, Mahesh M. (2017). Extent of adoption of potato production technology by the potato growers in Sabarkantha district of Gujarat. Agric. Update, 12(1): 75-83; DOI : 10.15740/HAS/AU/12.1/75-83. 